\title{
BASEL III: RETHINKING LIQUIDITY AND LEVERAGE
}

\author{
Isépy Tamása \\ ${ }^{a}$ Senior Lecturer, University of Pannonia, Department of International Economics, e-mail: isepy@almos.vein.hu
}

\section{ARTICLE INFO}

JEL classification: G21

Keywords:

- Basel III

- liquidity

- leverage

\begin{abstract}
In my study I focus on important topics of the new banking regulation Basel III: leverage and liquidity. Using linear regression I analysed banks' long term liquidity and leverage ratios and profitability in 12 emerging market, new member, countries and in 15 developed, old member, countries of the EU between 2008 and 2010. I point out that in EU12 there is negative relationship between profit and interbank market dependence in 2010, while positive correlation between profit and funding base stability ratio. In the case of EU15 there is a negative correlation between solvency and profitability in 2008, while the relationship is positive between capital quality - more Tier 1 capital - and profitability.

Furthermore, I have tested the Myers-Majluf theory with monthly aggregated equity issue and the Dow Jones financial institutions index changes relating to the eurozone between 1990 and 2011. According to this theory, equity issue leads to lower equity prices. I point out that on an aggregated level (eurozone) the theory cannot be proved. Myers-Majluf theory is particularly important in the process of banking recapitalisation, since it is this theory that dictates slower banking capitalisation. From the perspective of a macroprudential policy capital increase would be more beneficial than asset decrease.
\end{abstract}

Reference to this paper should be made as follows: Tamas J,. 2013. Basel III: Rethinking liquidity and leverage, Ekonomska istraživanja - Economic Research Special Issue 2013 
Isépy Tamás

\section{INTRODUCTION}

In Canadian banks' financing structure the proportion of deposit is higher than interbank funds. This can serve as an explanation to the higher stability of the banking system Ratnovski L., Huang R. (2009). The big banks with higher Tier 1 capital and higher deposit proportion among their liabilities at the end of 2006 could withstand the crises; moreover, they had higher profitability also Beltratti A., Stulz R. (2009).

In the academic debate about regulation - growth trade off, it is important to mention the costs of banking failures, which amounted to 1346,2 billion USD between 2007-2010. The figure relates to a review on 39 European and American banks, whose loss was caused by toxic securities as well as bad credits Reuters (2011).

In addition to the less transparent relationship-lending financing Calomiris $C$ and Kahn C. (1991) the wholesale interbank funding can be explained with higher credit opportunities and better credit monitoring possibility. Ratnovski L., Huang R (2008) already warned of the negative effect of arm's length financing during the crisis - wholesale interbank refinancing - if it is coupled with aggressive credit strategy, because it can cause a sudden drain of capital in case of negative information.

Kenneth R. French [et al.]'s (2010) suggestion with regards to the regulation of financial system are the following:

- ceteris paribus - since big banks hold also systemic risk, their required capital has to be higher than the proportional one. Brunnermeier [et al] (2009) would ask the countries to create a list about big banks and using macroprudential regulation, they would define their add-in to the systemic risk.

- the required capital needs to depend on the assets' liquidity the bank holds.

- the financial institutions' capital requirements must increase proportionally to their short-term liabilities.

Basel III allows a rather long period for banks to raise their capital BCBS (2010c) and MAG (2010). Arnold et al (2012) emphasize that capital is cheap and is available in appropriate quantities in times of upswing. Kashyap, Rajan, Stein (2008), Borio, Zhu (2008) underline that equity issue is particularly difficult in times of uncertainty. In times of crisis Stulz's (1999) thesis - globalisation decreases the cost of capital - can be vulnerable. Though Ayadi (2012) acknowledges the efforts of Basel Committee at increasing the capital quality, as well as working out liquidity and leverage ratios, he thinks that the length of the transition period will dilute these corrections and new regulations. Borio (2012) urges the recapitalisation of banks among the banking regulation measures - including the possibility of temporary state ownership -; moreover, he also urges the investigation and write-down of overall losses, the transparency of banks, the importance of bad assets' management in order to follow the Scandinavian example and not the Japanese one. While Scandinavian countries took these measures, Japan did not at the start of the 1990s' banking crisis.

One possible reason for the transition period's length is that equity issue is more expensive than bond issue and banking credit. Kashyap, Rajan, Stein (2008) As opposed to the traditional capital regulation, which takes the formar statement as a given - Admati et al (2010) call the assumption that equity is more expensive than bond a myth - they focus on investigating why banks consider capital as a more expensive fund? Knowing the reason "would reduce the drag of economic growth associated with capital regulation, as well as lower the incentives for regulatory 
arbitrage."

Gale (2010) warns that the raising of capital ratio forces banks to hold riskier assets in order to achieve the targeted return.

The high leverage of the financial institutions can have significant negative effects. Equity is the "expensive" form of liabilities. Admati and Pleiderer (2009) warn that these two contentions lead to trade off. Starting from Modigliani-Miller theorem they underline that equity is neither expensive nor cheap. The total cost of equity is influenced by several factors (taxes, cost of failure, agents' cost, information asymmetry) but this does not mean that the expected return is also higher. The issue of risk in the Basel Accord appears in inverse form. The riskier an asset or an offbalance sheet item is, the more capital needs to be ordered to this position.

IMF (2009) in Arnold et al (2012) claim that those markets where banks with leverage played a role became vulnerable more easily. The increase of leverage was not discovered by Basel II. The crisis starting in 2007 forced banking supervisions to enhance the current banking regulation requirements both on the national and the international level. Basel Committee on Banking Supervision developed a new banking regulation, Basel III, focusing predominantly on a new capital regime; in addition, it created new ratios for measuring liquidity and leverage.

The failure of lots of banks warns of the importance of new regulations. Emerging markets in the EU in particular need to face greater difficulties in fulfiling stricter requirements as regards capital, liquidity and leverage. The micro- and macroprudential views are totally different with respect to equity issue and the improvement of the capital adequacy ratio. In the micro view the choice between possible solutions (capital increase, asset shrinkage) is indifferent. From the macro point of view there is a great difference. "Fire sale" and the dramatic shrinkage of assets lead to serious consequences.

The requirements of capital increase will be put in place slowly over several years (2015 and 2018). The reason is the Myers-Majluf theorem from 1984, which claims that when corporations require additional sources, they turn to equity issue as a last resort only (pecking-order theory).

My paper is divided into five parts. The first part discusses leverage regulation in the old and the new regime. In the second part I analyse the current liquidity approach. In the third part I test the correlation between the available long-term liquidity, leverage ratios and profit in EU (old and new members). Since BIS quantitative impact studies provide available data only on bank type level, I only refer to their findings. I test moreover the Myers-Majluf theory - pecking order theory - claiming that equity issue leads to price fall in the short run. I analyse the aggregated equity issue in the eurozone. In the fourth, discussion, part, I underline my results in comparison to former studies. In the conclusion and results sections, I summarise the most important theses of my research and provide further suggestions with respect to improving the current banking regulation.

\section{ABOUT LEVERAGE}

The first graph presents return on equity data in 10 emerging market coutries in 2008, 2009 and 2010. Malta and Cyprus joined EU in 2004 but they will be treated as developed countries. 


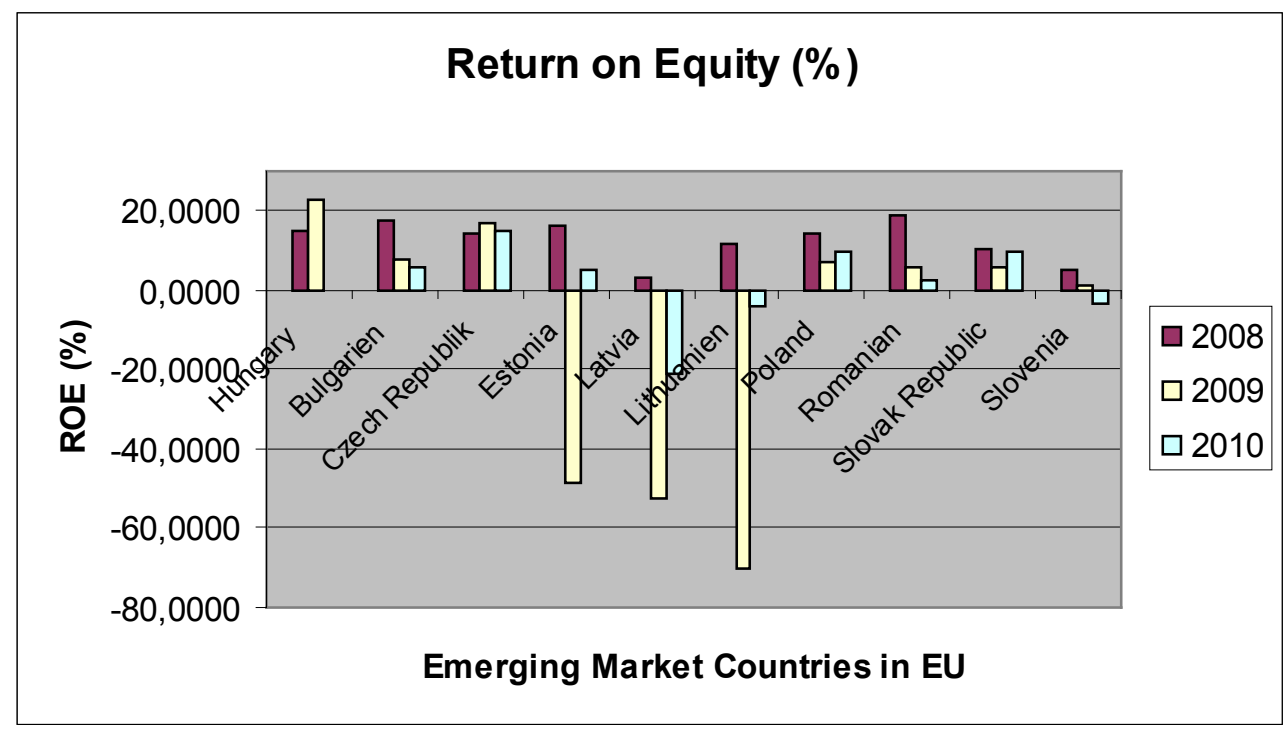

FIGURE 1. RETURN ON EQUITY IN THE EMERGING MARKET COUNTRIES OF THE EU Source: ECB Dataware

All countries had remarkable positive profit in 2008, but in 2009 the results are more varied. I highlight the fact that the Baltic states' banking systems had a solid loss since they had a loss amounting to $50 \%-70 \%$ of their capital. In 2010 the profit in Estonia is already positive, while in the other two Baltic states the loss decreased.

The second graph shows the return on assets in the ten emerging market countries in EU in 2008, 2009 and 2010.

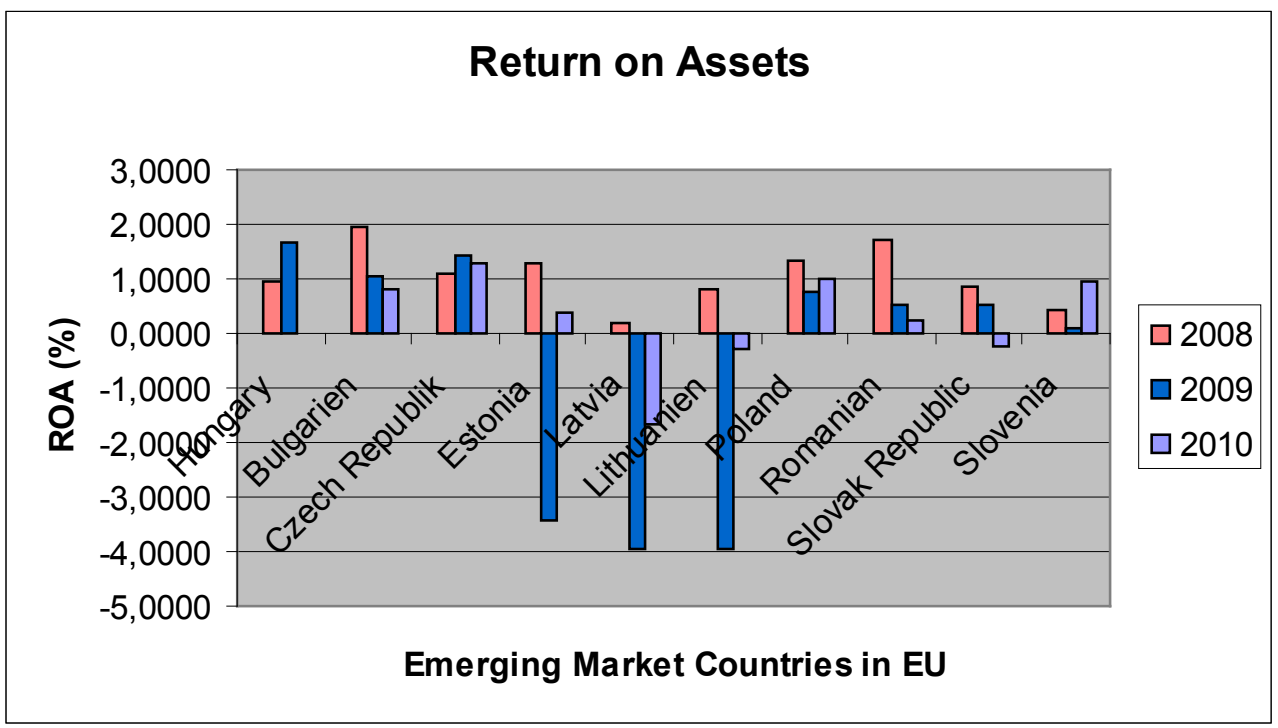

FIGURE 2. RETURN ON ASSETS IN THE EMERGING MARKET COUNTRIES OF THE EU Source: ECB Dataware, Author's calculations 
Basel III requires better capital; moreover, it creates a new leverage ratio. Capital adequacy ratio (CAR) is only an implicit measure of leverage. In 1988 8\% of CAR meant a 12,5-fold leverage for the whole credit portfolio regardless of the creditworthiness of clients. This ratio provides a lot of information in one figure on an aggregate level but a number of individual leverage ratios remain lacking in transparency, or, more precisly, these CAR figures (those of banks, countries) are not comparable from a leverage point of view. Since they contain credit, market, and operational risk constituents, they are only comparable with respect to the needed capital. Risk weighted assets in the nominator of the capital adequacy ratio are more complex and they contain information of both of the above mentioned risks.

There are no records of the mechanisms used to form CAR in the 1980s. On what fundamentum this ratio relies on remains hidden. The Basel Committee on Banking Supervision forced banks to disclose their leverage information with the application of the former ratio (5\%) of equity/assets - prescribed before the introduction of CAR, newly amended with off-balance sheet plus securitisation measure. The minimum level of the new leverage ratio is $3 \%$. In 1988, with CAR, BIS emphasized an implicit 12,5-fold leverage (for credit portfolio), while the new leverage ratio is 33,3 for the total position (on- and off-balance sheet) of the bank.

The capital/assets ratio CAR (capital adequacy ratio) is not eligible for the analysis of risks incorporated by banks and banking systems. There is a lack (and need) of a bank (micro) level and a bank system (macro) level ratio, which provide information about leverage. CAR contains several individual positions (for example, market risk positions) with different leverage ratios and with capitals ordered to the individual. In order to measure a bank's (with CAR of $8 \%$ ) real risk position on a bank or bank system level, there is a need to administer a stress test on the bank system level. Stress CARs are available on a bank system level, but not on a monthly basis. The former example shows that it is possible that a bank would need a CAR of $9 \%$ on a micro level, while another bank needs one of $8,5 \%$. Two banks, whose CARs are the same (10\%), have not the same risk assuming that one has an off-balance sheet item needing 4 units of capital, while the other has none.

\section{ABOUT LIQUIDITY}

In Basel III the liquidity risk issue represents a new approach. The short- and long-term ratio are to be calculated, however no capital needs to be ordered to liquidity risk. Basel III has a stricter capital regime than before, a number of banks will not be able to raise their capital in the requested manner from 2013 onwards.

I think that liquidity risk also needs to be examined. There are two possibilities: first, policymakers may decide that the net stable funding ratio and the liquidity coverage ratio cannot be less than a given amount. (This version is planned in Basel III.) The second possible solution is that more attention is paid to liquidity draught, which can cause serious losses. Therefore, a minimum of capital requirements needs to be calculated not only for the market risk, but for the liquidity risk also. Ex post to the crisis higher spreads are available for these liquidity dry up situations and the losses can be calculated. Ex ante liquidity at risk modelling can also be a good proxy for amending market risk calculations.

The different types of market participants on derivatives - hedgers, arbitrageurs, speculants - have also some relevance with respect to liquidity. Hedgers can only have partners on the market when there is enough speculation. Moreover, arbitrageurs have an add-in for efficient price systems Scholes (1969), Gehrig and Zimmermann (1996). This phenomenon is most important because without their participation carry trade suffers distortions. Liquidity draught on short- 
Isépy Tamás

term FX swap can be explained by the decreasing number of arbitrageurs and speculation on the market. The lengthening of the refinacing position of the bank's liabilities has an effect on the yield curve; moreover, it can encourage these market participants.

It obviously rarely happens that there is a drought on the foreign exchange market (to be more precise, only on one part of the FX market - FX swap market) or on the money market, but it also needs to be considered. If the banking system refinance their long term assets in Swiss Franc with a three-month interest period, in case of a liquidity dry up the liquidity risk will turn into a market risk. In this case, the banking system or individual banks run not only interest rate risks but foreign exchange risks also. For this reason, I believe, an appropriate level of capital needs to be ordered to this position also. Presumably, periods of liquidity draught last only for short periods of time, but the needed capital has to be ordered for positions containing liquidity risks using the previously mentioned methodology.

Bleackley and Cowan (2010) analysed corporates (non-financial institutions) and found that a firm's investment response does not depend on their liability's structure. This result contradicts the maturity mismatch hypothesis, which claims that after liquidity shocks firms with shorter term liabilities do remarkably less investment than those with longer-term liabilities.

The new banking regulation Basel III does not propose capital for liquidity risk but will force banks to take measures if they do not meet their long-term liquidity requirements. They have three options:

- decreasing their maturity mismatch

- increasing the proportion of longer term funds

- reducing their financial assets.

The Modigliani-Miller (1958) theorem is only applicable in complete markets since on the macro level, and on a country basis also, the quality, proportion, and maturity of liabilities can influence the profitability of a banking system.

Bleakley H., Cowan, K., (2010) emphasize that "unfortunately, the 'macro' observation that crises occur with greater frequency in economies that have more short term indebtedness (or more short term indebtedness relative to international reserves) does not constitute sufficient evidence of this mechanism". They investigated corporations in emerging markets.

ECB (2010) emphasize that the reason to allow a longer introduction period for the two liquidity measures is "to ensure that the new measures do not represent an excessive burden on the financial sector".

Table 1 shows the time schedule for the introduction of liquidity and leverage ratios. 
TABLE 1. PHASE-IN ARRANGEMENTS OF LIQUIDITY'- AND LEVERAGE RATIOS' I MPLEMENTATION

\begin{tabular}{|c|c|c|c|c|c|c|c|c|c|}
\hline & 2011 & 2012 & 2013 & 2014 & 2015 & 2016 & 2017 & 2018 & 2019 \\
\hline $\begin{array}{c}\text { Levarage } \\
\text { ratio }\end{array}$ & $\begin{array}{l}\text { Supervisory } \\
\text { monitoring }\end{array}$ & & Parellel r & un $1 \operatorname{Jan} 2$ & $\begin{array}{l}013-1 \operatorname{Jan} 20 \\
1 \text { Jan } 2015\end{array}$ & 7 Disclos & e starts & $\begin{array}{c}\text { Migration } \\
\text { to Pillar } 1\end{array}$ & \\
\hline $\begin{array}{c}\text { Liquidity } \\
\text { coverage } \\
\text { ratio }\end{array}$ & $\begin{array}{l}\text { Observation } \\
\text { period begins }\end{array}$ & & & & $\begin{array}{l}\text { Introduce } \\
\text { minimum } \\
\text { standard }\end{array}$ & & & & \\
\hline $\begin{array}{c}\text { Net stable } \\
\text { funding } \\
\text { ratio }\end{array}$ & & $\begin{array}{l}\text { Observa- } \\
\text { tion period } \\
\text { begins }\end{array}$ & & & & & & $\begin{array}{l}\text { Introduce } \\
\text { minimum } \\
\text { standard }\end{array}$ & \\
\hline
\end{tabular}

Source BIS (2010a)

\section{QUANTITATIVE ANALYSIS}

\section{METHODOLOGY AND DATA}

Since ECB dataware is not complete regarding the derivatives of emerging market countries in EU, moreover, BIS maintains only aggregate derivative data of the different groups of countries, there is no appropriate ratio for leverage available.

According to the comprehensive quantitative impact study published by BIS (2010b), the leverage ratio for large banks is $2,8 \%$ - so below the $3 \%$ limit -, while for smaller banks it is $3,8 \%$. Large banks have higher leverage and so a smaller leverage ratio. Thus, on average, large banks currently do not fulfill the leverage requirements. The 30 -day liquidity coverage ratio (LCR) suggested by BIS for large banks is $83 \%$ on average, while for smaller banks it is $98 \%$. The net stable funding ratio, which highlights the liquidity mismatch of large banks, is $93 \%$, while for smaller banks it is $103 \%$.

Usually, BIS databases contain only aggregate data unsorted by countries. The data ECB maintain on a country level, however, are not exactly these liquidity ratios.

Here are the BIS suggested ratios for liquidity and leverage purposes:

Leverage ratio $=$ Tier 1 / (bank's non-weighted assets + off-balance sheet $)$

Liquidity coverage ratio $=$ stock of high quality assets $/$ net cash-outflows over 30-day time period

Net stable funding ratio $=$ (available amount of stable funding $/$ required amount of stable funding) $>100 \%$ BIS (2009)

Currently for the BIS suggested Net stable funding ratio the data coming from ECB Data- 
Isépy Tamás

ware - Funding Base Stability Ratio and Interbank market dependence can be used. The first ratio shows the proportion of longer term refinancing sources of the banking system of an individual country. In case of interbank market dependence, I assume that higher ratio means shorter-term funds. The interbank market is typically within the time span of one year, and banks prefer to refinance their position in the market on shorter- rather than on longer-terms because it is cheaper. Maturity mismatch data are not available. These two ratios published by ECB Dataware however can be seen as implicit maturity mismatch ratios on a country level. The former BIS ratio will be introduced only in 2013, so the one published by ECB is the only one available and appropriate for stability calculation purposes.

BIS defines two liquidity ratios. The first is the liquidity coverage ratio (LCR), which defines the liquidity sufficient within a 30-day period, the other is the net stable funding ratio, which underlines the importance of funds providing a long-term stability.

For the following regression analysis, instead of the BIS suggested Net stable funding ratio, I have used two others which are similar and are available in ECB Dataware between 2008 and 2010 for comparative country analysis. The first is Funding Base stability ratio ${ }^{1}$ and the other is Interbank market dependence ${ }^{2}$.

TABLE 2. LINEAR REGRESSION ANALYSIS IN EU12 AND EU 15 COUNTRIES ROA, ROE AND EXPLANATORY VARIABLES

\begin{tabular}{|c|c|c|c|c|c|c|c|c|c|}
\hline EU 12 & 2008 & 2009 & 2010 & VIF (2010) & $\begin{array}{l}M \quad U \\
(E U 15)\end{array}$ & 2008 & VIF(2008) & 2009 & 2010 \\
\hline $\mathrm{ROE}$ & & & & & $\mathrm{ROE}$ & & & & \\
\hline FBSR & 0,247 & 0,128 & $0,82^{* *}$ & 4,826 & FBSR & $-0,333$ & 1,13 & 0,318 & 0,296 \\
\hline OS & 0,196 & $-2,601$ & 2,748 & 923,672 & OS & $-1,669$ ** & 6,967 & 1,019 & 0,493 \\
\hline LD & 0,207 & 0,144 & $-0,697^{* * *}$ & 1,151 & LD & $-0,038$ & 1,374 & 0,574 & 0,187 \\
\hline TETA & 0,288 & $-0,012$ & $-0,606^{*}$ & 8,206 & TETA & 0,438 & 2,232 & 0,196 & 0,157 \\
\hline Tier 1 & 0,137 & 2,862 & $-1,831$ & 829,319 & Tier 1 & $1,169^{*}$ & 8,374 & $-0,831$ & $-0,32$ \\
\hline$R^{2}$ & 0,405 & 0,483 & 0,965 & & $R^{2}$ & 0,872 & & 0,492 & 0,175 \\
\hline Sig & & & 0,005 & & Sig. & 0,028 & & & \\
\hline $\mathrm{ROA}$ & 2008 & 2009 & 2010 & & ROA & 2008 & & 2009 & 2010 \\
\hline IMD & $-0,25$ & $-0,314$ & $-0,835^{*}$ & 7,217 & IMD & 0,442 & 2,586 & $-0,335$ & 0,124 \\
\hline OS & 0,149 & $-1,512$ & 3,173 & 1254,626 & OS & $-1,613^{* *}$ & 7,261 & 1,325 & 0,18 \\
\hline LD & $-0,259$ & $-0,273$ & $-0,446^{* *}$ & 1,585 & LD & $-0,264$ & 1,822 & 0,823 & 0,236 \\
\hline TETA & 0,702 & $-0,014$ & $-0,238$ & 8,598 & TETA & 0,476 & 2,267 & 0,15 & 0,146 \\
\hline Tier 1 & $-0,494$ & 2,038 & $-2,472$ & 1128,377 & Tier 1 & 0,879 & 8,912 & $-1,078$ & $-0,166$ \\
\hline$R^{2}$ & 0,762 & 0,678 & 0,943 & & $R^{2}$ & 0,86 & 0,473 & 0,123 & \\
\hline Sig & & & 0,013 & & Sig & 0,034 & & & \\
\hline
\end{tabular}

Source: ECB SDW, Author's calculation 
I investigated the profitability datas (ROE, ROA) of the banking system in EU12 (new) and EU15 (old) countries with linear regression analysis - with OLS. The explanatory variables were available between 2008 and 2010, therefore I prepared a cross-country analysis for each year.

The explanatory variables in case of ROE are:

FBSR - Funding Base Stability Ratio

OS - Overall Solvency

LD - Loan/Deposit

TETA - Total Equity/Total Assets

Tier1 - The best quality capital in percentage of the total assets

In case of ROA:

IMD - Interbank Market Dependence

OS - Overall Solvency

LD - Loan/Deposit

TETA - Total Equity/Total Assets

Tier1 - Best quality capital in percentage of the total assets

Results can be interpreted as follows. There is significant correlation in old EU member states in 2008, while in new member states in 2010 between the individual explanatory variables and return on equity (ROE) and return on assets (ROA). It is important to mention that the quantity of capital increased in NMS during the examined period, while the asset expansion is due to the increase of the Polish banking system's assets almost exclusively. In the OMS the relationship cannot be justified after the beginning of the debt crisis starting in 2009.

For the New Member States (EU12) in 2010 FBSR, LD, and TETA are significant explanatory variables in the case of ROE, while in the case of ROA, IMD and LD have explanatory value. Between FBRS and ROE there is positive correlation, meaning a growth of $1 \%$ in FBRS will increase ROE by $0,82 \%$. Between LD ratio ${ }^{3}$ and ROE, as well as ROA, the relationship is negative, that is, the increase of this ratio decreases profitability. This result contradicts the OMS results, because there the correlation's coefficient is positive. The TETA - total equity / total assets - ratio is significant only in case of ROE, where the coefficient is negative, which can reflect the riskiness of equity capital. In the case of ROA the IMD - interbank market dependence -, not surprisingly, negatively affects profitability. Linear regression analysis for both profitability ratios (ROE, ROA) amounted higher than $0,9 \mathrm{R}^{2}$ measures.

For multicollinearity checks I used VIF (Variance Inflation Factor) and found that the critical value of 10 (SPSS) is not exceeded in cases of significant correlations.

\footnotetext{
${ }^{1}$ Deposits from customers / (funds from credit institutions + funds from depositors (but not from credit institutions) + total bonds)

${ }^{2}$ Funds from credit institutions / total liabilities

${ }^{3}$ The targeted ratio is between $110 \%$ and $150 \%$, higher values mean higher vulnerability of the countries banking system. Source:ECB Financial Stability Review June 2012
} 
Isépy Tamás

In EU15 - OMS in 2008 the Overall Solvency ratio increase by 1\% resulted 1,6\% down of both profitability measures. Lower leverage was coupled with lower profitability in 2008. This contradicts Harris, Raviv's (1991) and Rajan, Zingales's (1995) results, who found lower profitability in cases of higher leverage. The result may be linked with too high levels of capital buffers. The average measure of CAR was $12 \%$ and it rose to $14 \%$ in 2010.

One needs to pay more attention to ROE, which was negative on average in $2008(-1,44 \%)$. This was caused by the data preliminary of the Belgian (-44\%), Dutch $(-11,7 \%)$, German $(-9,7 \%)$, and British $(-9,7 \%)$ banking systems. In the next two years the average ROE figures are already positive, but the Irish banking system's extraordinary loss (2009:-36\%, 2010:-65\%) modified the average banking system data downward.

The increase of Tier 1 capital by $1 \%$ increased profitability by $1,1 \%$. This result supports the goal formed in Basel III, namely, setting higher quality and quantity capital requirements for the banks. $R^{2}$ measures were in both cases near to $0,9(0,87 ; 0,86)$. The fact that there is a lack of significant relationship between LMD, FBRS and profitability ratios can mean the higher quality of the EU15 banking systems. In 2010, considering the banking assets, the EU15 banking system was 40 times bigger than the EU12 one.

\section{MYERS-MAJLUF TEST}

Between 1990 and 2011 I investigated the monthly net equity issue in the eurozone as well as the ratio with total market capitalisation and the monthly changes of the Dow Jones eurozone financial institutions data. Since equity prices react on the new information immediately, I analysed the same month for both $D$ J index monthly changes and the ratio of issued capital divided by market capitalisation to uncover the relationship. I found that the correlation coefficient for new equity issues and the monthly index return on an aggregate level (there were no financial institutions equity indices for the individual countries available) is negative, but the relationship is not significant.

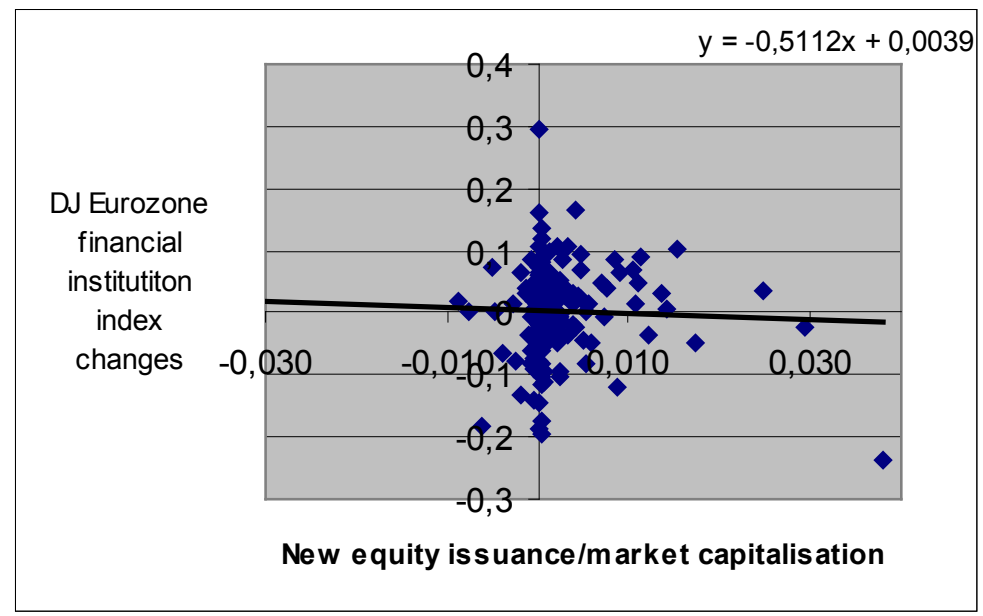

FIGURE 3. NEW EQUITY ISSUE / TOTAL MARKET CAPITALISATION AND DOW JONES EUROZONE FINANCIAL INSTITUTION INDEX CHANGES (1990 JANUARY - 2011 DECEMBER)

Source: ECB Dataware, Author's calculation 
Asquith és Mullins (1986) found 3\% equity price fall on average at equity issue in their study. Masulis (1980) investigated the two-day equity price responses and pointed out a $-5,4 \%$ average change. In the examined period there were in more than $84 \%$ of 57 equities negative returns in the period of two days after disclosure.

The time series examined do not contain bank-level data, only aggregated monthly data for countries and the Euroregion. Therefore, I modified the data and pointed out the following relationship. The index fell by nearly $23 \%$ in 2008 October at the issueance of $3,8 \%$ of the total market capitalisation. This fall cannot be interpreted with the help of Myers-Majluf theory, since it is the first month of the crisis. For this reason, I removed it from the time series as extreme data.

It is assumed that the aggregated time series represents an individual equity. In this case small equity issuances are disregarded since they could lead to distorted results. I have used only those issued capital quantities that influence the equity index. Considering only equity issues higher than $0,5 \%$ of the total market capitalisation, the following result can be concluded. There is no relationship between equity issue and equity return on an aggregated level, since the resulting graph is an almost flat line.

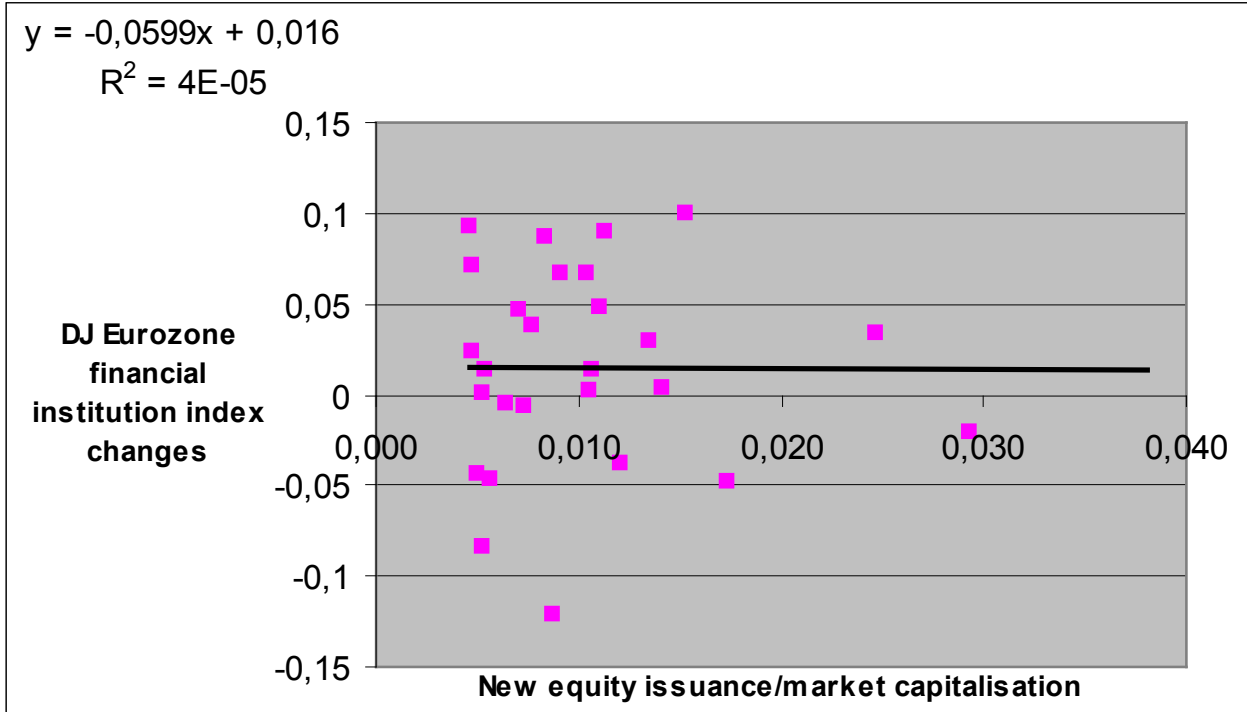

FIGURE 4. EQUITY ISSUE AND EQUITY INDEX RETURN. CORRECTED DATASET (28 CONSIDERATIONS)

Source: ECB SDW database, Author's calculation

Using the aggregated corrected time series and having tested the Myers-Majluf pecking order theory, I was led to the conclusion that in the examined period it cannot be stated that equity issues are coupled with equity index fall.

Obviously, ideally, one should compare bank level equity issuance and bank level equity price returns. Lacking these data, the given data - namely, monthly country level new issuance divided by market capitalisation and the Dow Jones Eurozone financial institution index available on a monthly basis - yield the former relationship. 


\section{DISCUSSION}

In the international literature IMF (2012) investigated 37 big banks' monthly data in the EU between 2006-2008 and 2009-2011 and found that there is positive correlation between higher capital buffers, capital ratios and equity returns in the second period, while in the first period there is positive significant correlation only between capital buffers and equity price development. In the second period for example Tier $1 /$ RWA ratio up by $1 \%$ resulted $0,5 \%$ in 1 month equity price returns. These results can encourage economic policy makers to move towards the further recapitalisation of banks.
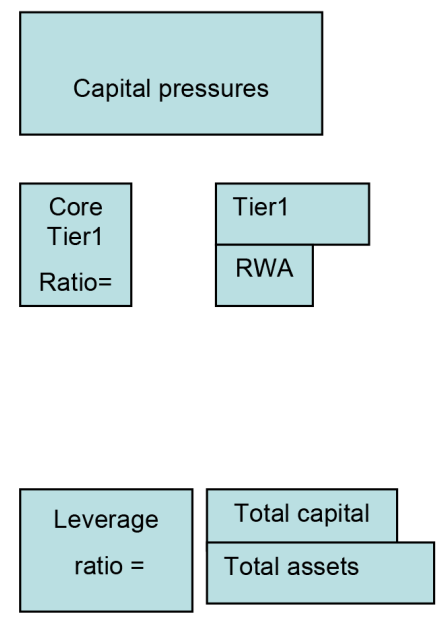

\section{-Sell-off of business lines} -Disposal of liquid assets -Non- renewal of maturing loans -Restrict new lending

-Debt-to equity conversion -Retain earnings -Equity issuance -Increase deposits - Increase long-term wholesale funding
Funding/liquidity pressures
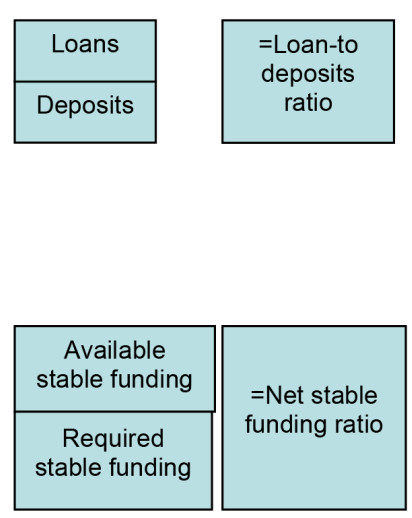

FIGURE 5. RELATIONSHIP BETWEEN DELEVERAGING AND LIQUIDITY AND CAPITAL RATIOS Source: ECB (2012)

The ECB (2012) study shows the possibilities for increasing CAR. Evidently, Basel III primarily privileges the raising of good quality capital (Tier1) among other possible solutions. The deleveraging process actually relies on two major strategies. The first is the decrease of Risk Weighted Assets (both non- and off-balance sheet items) and the second is the increase of capital.

Presumably, the strict prescriptions for Tier 1 will accrue concerns for small banks, which will not be able to fulfill the requirements in 2015 and 2018, respectively.

The ECB (2012) study emphasizes the positive externalies at the analysis of the deleveraging assessment, while Hanson, Kashyap and Stein (2011) focus directly on the extremely important difference between the micro- and macroprudential views. On the micro level it is indifferent whether financial institutions lower their financial assets or increase their capital, because both measures lead to increased CAR. On the macro level, however, there is a difference. If banks opt for decreasing their assets, this can lead to restricted lending and/or liquidity problems. The shrinkage of financial assets can cause credit crunch and fire-sale. Particularly in illiquid markets, wholesale selling intentions can result in significantly falling prices.

Considering the fact that equity issuance is risky, banks opt for this solution to a lesser extent. Myers and Majluf (1984) in their study pointed out that market participants think a new equity issuance is a sign that according to the management estimate the equities are overvalued, 
so the market reacts to the issuance by decreasing the equity price. The pecking order theory Myers (2001) states that corporations prefer borrowing money to equity issuance.

First, there is a pressure to push banks towards a higher level- and quality capital position, secondly, however, this can mean disadvantages for banks also. Two remarks here follow as to how this disadvantage can be lessened:

- first, if banks do not hold their own equity, they are not directly affected by the equity price fall after issuance; at the most, their later equity issuance can be managed only at a lower equity price.

- Second, Kashyap, Stein, Hanson (2010) proved that lowering the leverage leads to decreasing the volatility of returns; thus, equity as fund becomes less risky and, therefore, the cost of equity will be smaller.

The introduction is planned already in 2013, but data disclosure is only obligatory after 2015. The equity / assets ratio minimum is $3,5 \%$ in $2013,4 \%$ in 2014 , while $4,5 \%$ in 2015 . The Tier 1 is $4,5 \%$ in $2013,5,5 \%$ in $2014,6 \%$ in 2015 . The liquidity ratios will be implemented in 2015 , Liquidity Coverage Ratio, and Net Stable Funding Ratio in 2018.

\section{CONCLUSION}

The Interbank Market Dependence ratio and the Net Stable Funding ratio are both applicable for the preliminary tests of liquidity shocks and for the formation of further requirements. Policy makers may set a maximum for IMD on a macro level, which could be a maximum target level in the whole banking sector. The Net Funding Base Stability ratio gives information about the banks' own funds and deposits. Here a required minimum level can also be put in place. These two ratios are both applicable for measuring the long-term maturity mismatch.

BIS made efforts to ensure a stronger and better capital both on a bank and a bank system level, but they did not translate liquidity risk into capital adequacy. Wellink (2010) emphasizes that the crisis starting in 2007 is not the crisis of Basel II since most of the banks started to introduce Basel II only in 2008. I agree with him; at the same time, I think that it is a mistake that Basel II does not state capital requirements for covering the liquidity risk. No such requirement is part of Basel III either; maybe Basel IV will incorporate it.

The Basle Committee developed and proposed two new liquidity risk measures: the first for the short term liquidity stress and the second for liquidity mismatches. The Liquidity Coverage Ratio will be adopted from 2015 on, the Net Stable Funding Ratio will be put in place as a minimum requirement in 2018.

I suggest that for the transition period until 2015 and 2018 some limit derived from the liquidity risk needs to be implemented since in the current crisis the bank system's withstanding ability was affected not only by its capital but also by its liquidity. On the national banking supervision level these liquidity ratios can be implemented or used as early warning tools.

Goldstein and Turner in BIS (2010) underline that regulators need to monitor the maturity mismatch not only on the micro- but also on the macro level since individual financial institutions can overestimate their capability to overcome foreign exchange- and interest rate risks during short periods of crisis. This is the so-called macroprudential dimension. Liquidity risk "appears" in the form of, or is converted into, interest rate- and foreign exchange risks. 
Isépy Tamás

Obviously, the macroprudential policy perspective can be seen as a top-down approach, while the microprudential one is a bank level policy. These two approaches need to work side by side each other. If the macroprudential policy prescribes high - over the minimum CAR - capital buffer, the modelling on the micro level will have less relevance. If the supervisory authority requires a macroprudential capital level above the microprudential capital niveau, the question is whether it should be done proportionally to the RWA or there is a need for setting leverage ratio for the bank system.

Basel II allowed internal models for credit risk in spite of the standard approach at reckoning customer creditworthiness. This could however not hinder the banks' efforts to decrease their capital requirements on the micro-level significantly, using their internal models similar to market risk calculations.

On the one hand, it is true that the crisis started not at the implementation of Basel II, but Basel III also can only partly meet today's challenging requirements.

Between 2007 and 2010 the American banks' ROA was -7\% IMF (2010), which means that only a CAR higher than $8+7 \%=15 \%$ (due to the asset weighting in the nominator) could have withstood the unestimated losses.

Basel III focused among others on bank capital quality. Swary (1980), Maisel (1981) in Kapstein (1991) think that there is no correlation between bank capitalisation and bank failures. Kapstein (1991) thinks this hardly imaginable since capitalisation means transparency and confidence on the liability side (in case of avoiding eventual deposit drain), secondly, capitalisation plays a significant role in the estimation of historical credit default.

I think Basel II was not able to lessen the crisis. Certainly, regulation lags behind market developments. Perhaps Basel I simply prescribed uniformly higher capital requirements for credit risk than economically needed. In good times regulatory capital requirements were significantly above the economic capital. In 2007 banks applied Basel I preparing themselves for the implementation of Basel II.

Before the introduction of Basel I the capital /assets ratio was $5 \%$, in Basel III the same ratio is defined as a minimum of $3 \%$. In this context the $-7 \%$ ROA is extremely high. Policy makers have to take the recapitalisation possibilities of smaller banks into consideration, moreover, the disadvantages financial intermediaries in competition when prescribing higher capital requirements. At the same time, they cannot delay in setting capital buffers needed for macroprudential reasons as well as in introducing the requirements of liquidity risk adjusted CAR, which measures will presumably appear in Basel IV. 


\section{RESULTS}

The pressures caused by banking regulation in the coming years can affect several banks seriously. I have tested the Myers-Majluf theory and concluded that the pecking-order theory can be proved on aggregated level only with corrected data and that on average new equity issuance leads to only a slight equity price fall. With sorted data - 28 data between 1990 and 2011 - where equity issuance is higher than the $0,5 \%$ of the current market capitalisation of the eurozone financial institutions, the theory cannot be stated.

I believe that the analysis of this area is particularly important since the reason for delayed capital increase lies in this theory, namely, that new equity issuance decreases the price of equity. This is why bank managers are reluctant to issue equity in order to raise CAR; they rather prefer to shrink their financial assets. This measure, however, includes macroprudential dangers due to fire sales and credit crunch. It is important to foreground the arguments of the macroprudential policy: equity issuer banks are affected by the falling equity prices directly only in the case when they are holders of their own equity, while indirectly only later to the extent of the success of new equity issuance. Therefore, the delay in the banks' capitalisation is emprically not fully justified.

I analysed banks' profitability ratios (ROE and ROA) between 2008 and 2010 in EU15 and EU12 and I sought to to uncover the relationship between liquidity ratios (defined by Basel III) - Liquidity Coverage ratio and Net Stable Funding ratio - and capital- and leverage ratio. I was led to the conclusion that the correlation was significant in EU12 in 2010, while in EU15 in 2008. In EU12 I found correlation preliminary between liquidity ratios - in ECB Dataware net stability ratios - Funding Base Stability ratio and Interbank Market Dependence and profitability. That is, higher FBSR and lower IMD resulted in significantly higher profitability. In EU15, however, I found significant relationship between capital/leverage ratios and profitability. I pointed out negative significant correlation between Overall Solvency, and positive significant correlation between capital quality (Tier1) and profitability. 


\section{REFERENCES}

Admati A. R., Pfleiderer P. (2010): Increased Liability Equity: A Proposal to Improve Capital Regulation of Large Financial Institutions, Graduate School of Business Stanford University 2010 June

Admati [et. al.] (2010): Fallacies, Irrelevant Facts, and Myths in the Discussion of Capital Regulation: Why Bank Equity is Not Expensive, The Rock Center for Corporate Governance at Stanford University Working Paper Series No. 86 Stanford GSB Research Paper No. 2063

Arnold [et. al.] (2012): Systemic risk, amcroprudential policy framework, monitoring financial systems and the evolution of capital adequacy, Journal of Banking and Finance 36 (2012) 3125-3132

Asquith and Mullins (1986): Equity Issues and Offering Dilution, Journal of Financial Economics 1986

Ayadi R. (2012): On the Basel Regulation and Banks Incentives 65-90 in New Paradigm in Banking, Financial Markets and Regulation? Ed. Balling M., Liermann F., Spiegel F. v d., Ayadi R., Llewellyn D.T. SUERF Study 2012/2

Basel Committee on Banking Supervision (2009): Consultative Document - International framework for liquidity risk measurement, standards and monitoring, December 2009

Basel Committee on Banking Supervision (2010a): The Basel Committee's response to the financial crisis: report to the G20, October 2010

Basel Committee on Banking Supervision (2010b): Results of the comprehensive quantitative impact study December 2010

BCBS (2010c): Basel III: A global regulatory framework for more resilient banks and banking systems, 2010

Beltratti A., Stulz R. (1999): Why did some banks perform better during the credit crisis? A crosscountry study of the impact of Governance and Regulation NBER Working Paper No 15180 July 2009

Bleakley, H, Cowan, K. (2010): Maturity mismatch and financial crises: Evidence from emerging market corporations, Journal of Development Economics 93 (2010)

Brunnermeier [et. al.] (2009): The Fundamental Principles of Financial Regulation, Geneva Reports on the World Economy - Preliminary Conference Draft 11

Borio, Zhu (2008) Capital regulation, risk taking and monetary policy: A missing link in the transmission mechanism? BIS Working paper No 268 December 2008

Borio C. (2012). On time, stocks and flows: Understanding the global macroeconomic challenges BIS Study 2012

Calomiris C. és Kahn C. (1991): The Role of Demandable Debt in Structuring Optimal Banking Arrangement The American Economic Review, 81 (3): 497-513

ECB (2010): Financial Stability Review, December 2010

ECB (2012): Financial Stability Review - June 2012 
French K. R. [et. al.] (2010): The Squam Lake Report - Fixing the financial System, 2010 Princeton University Press

Gale D.(2010): Capital Regulationand Risk Sharing, International Journal of Central Banking, Vol. 6. No.4. 187-204 December 2010

Gehrig, B., Zimmermann, H. (1996): Fit for Finance, Verlag Neue Zürcher Zeitung

Hanson S., Kashyap A. K., Stein J. C. (2011): A Macroprudential Approach to Financial Regulation, Journal of Economic Perspectives 25 (1) pp. 3-28

Harris, Raviv (1991): The theory of capital structure, Journal of Finance, Vol. 46, 1991, pp. 297-355.

IMF (2010): Global Financial Stability Report 2010 April

IMF (2012): Global Financial Stability Report, Chapter 2 Sovereigns, Banks, and Emerging Markets: Detailed Analysis and Policies, April 2012

Kapstein E. B. (1991): Supervising International Banks: Origins and Implications of the Basle Accord, Essays in International Finance No. 185, December 1991, International Finance Section, Department of Economics Princeton University

Kashyap A. K., Rajan R. G., Stein J. C. (2008): Rethinking Capital Regulation 2008 Federal Reserve Bank of Kansas City Symposium

Kashyap, Stein, Hanson (2010): An Analysis of the Impact of "Substiantially Heightened" Capital Requirements on Large Financial Institutions, Clearing House Association L.L.C.

Macroeconomic Assessment Group established by the FSB and BCBS : Interim Report - Assessing the macroeconomic impact of the transition to stronger capital and liquidity requirements 2010

Masulis, R. W. (1980) The effects of capital structure change on security prices: A study of exchange offers, Journal of Financial Economics, Vol. 8, Issue 2, June 1980 Page 139-178

Modigliani-Miller (1958): The Cost of Capital, Corporation Finance, and the Theory of Investment, American Economic Review, XLVII (June 1958), pp. 261-297

Myers S. C., Majluf N. S. (1984): Corporate financing and investment decisions when firms have information that investors do not have, Journal of Fianancial Economics, Vol. 13, No 2, (June 1984), pp. 187-221

Myers S. C. (2001): Capital structure, The Journal of Economic Perspectives, Vol. 15. No. 2. (Spring, 2001), pp. 81-102

Rajan, Zingales (1995): What do we know about capital structure? Some evidence from international data, Journal of Finance, Vol. 50, 1995, pp. 1421-60.

Ratnovski L., Huang R. (2008): The Dark Side of Wholesale Funding Wharton Financial Institutions Centre 2008/ 40 Working Papers series

Ratnovski L., Huang R. (2009) Why are Canadian banks more resilient? IMF Working Papers WP/09/152 2009

Reuters (2011) in portfolio.hu Melyik bank mennyit bukott? - Íme a friss lista 2011.02.25 14:11 
Isépy Tamás

Scholes M. (1969): "A Test of the Competitive Market Hypothesis: An Examination of the Market for New Issues and and Secondary Offerings (PhD. Dissertation, University of Chicago 1969)

Stulz R. M. (1999): Globalization of equity markets and the cost of capital, February 1999, SBF/ NYSE Confernece on Global Equity Markets

Wellink, N. (2010): A new regulatory landcape, at the 16th International Conference of Banking Supervisors, Singapore 22 September 2010 